\title{
Erratum to "PECS Block Provides Effective Postoperative Pain Management for Breast Cancer Surgery-A Retrospective Study", [International Journal of Clinical Medicine, 2017, 8, 198-203]
}

\author{
Ichikawa Yuki ${ }^{1}$, Hironobu Ueshima², Hiroshi Otake², Akira Kitamura1 \\ ${ }^{1}$ Department of Anesthesiology, Saitama Medical University International Medical Center, Saitama, Japan \\ ${ }^{2}$ Department of Anesthesiology, Showa University Hospital, Tokyo, Japan \\ Email: yukiichikawa8@gmail.com
}

How to cite this paper: Yuki, I., Ueshima, H., Otake, H. and Kitamura, A. (2021) Erratum to "PECS Block Provides Effective Postoperative Pain Management for Breast Cancer Surgery-A Retrospective Study", [International Journal of Clinical Medicine, 2017, 8, 198-203]. International Journal of Clinical Medicine, 12, 34-35. https://doi.org/10.4236/ijcm.2021.121005

Received: January 7, 2021

Accepted: January 18, 2021

Published: January 21, 2021

Copyright $\odot 2021$ by author(s) and Scientific Research Publishing Inc. This work is licensed under the Creative Commons Attribution International License (CC BY 4.0).

http://creativecommons.org/licenses/by/4.0/
The original online version of this article (Ichikawa Yuki, Ueshima Hironobu, Hiroshi Otake, Akira Kitamura (2017) PECS Block Provides Effective Postoperative Pain Management for Breast Cancer Surgery-A Retrospective Study. International Journal of Clinical Medicine, 8, 198-203.

https://doi.org/10.4236/ijcm.2017.83019) unfortunately contains some mistakes. The author wishes to correct the errors in pain management tools, method, and figures.

Our article had some mistakes in pain management tools, method, and figures. The followings are the list of errata and correct figures.

\section{[List of Errata]}

Hiroshi Otake, who was certified as an imperfect co-author in the original paper, participated at all terms in the prepared process for the errata paper.

\begin{tabular}{lll}
\hline & TRUE & FALSE \\
\hline $\begin{array}{l}\text { P.198 2nd line of Abstract } \\
\text { P.199 10th line of Materials and Methods }\end{array}$ & $\begin{array}{l}\text { total or partial } \\
\text { mastectomy }\end{array}$ & $\begin{array}{l}\text { modified radical } \\
\text { mastectomy }\end{array}$ \\
$\begin{array}{l}\text { P.202 4th line of Conclusions } \\
\text { P.198 7th line of Abstract }\end{array}$ & numeric rating scale & visual analog scale \\
$\begin{array}{l}\text { P.199 6th line of Materials and Methods } \\
\text { P.202 1st line of Conclusions }\end{array}$ & numeric rating scale (NRS) & visual analog scale (VAS) \\
\hline \begin{tabular}{l} 
P.199 last line \\
\hline
\end{tabular}
\end{tabular}




\section{Continued}

\begin{tabular}{lll}
\hline P.200 7th line of Result & & \\
P.201 1st line of Discussion & NRS & VAS \\
P.202 12th from top & & 11 \\
& 12 & 27 \\
P.200 3rd line of Table 2 & 35 & 0.016 \\
\hline $\begin{array}{ll}\text { P.200 3rd line of Table 2 } \\
\text { P.198 7th line of Abstract }\end{array}$ & 0.0013 & \\
$\begin{array}{l}\text { P.199 7th and last line of Materials and } \\
\text { Methods }\end{array}$ & $0,0-4,4-6,6-12$, & $0,1,2,4,6,12,24$ hours \\
P.200 5th line & $12-24$ hours & \\
P.202 1st line of Conclusions & & \\
\hline
\end{tabular}

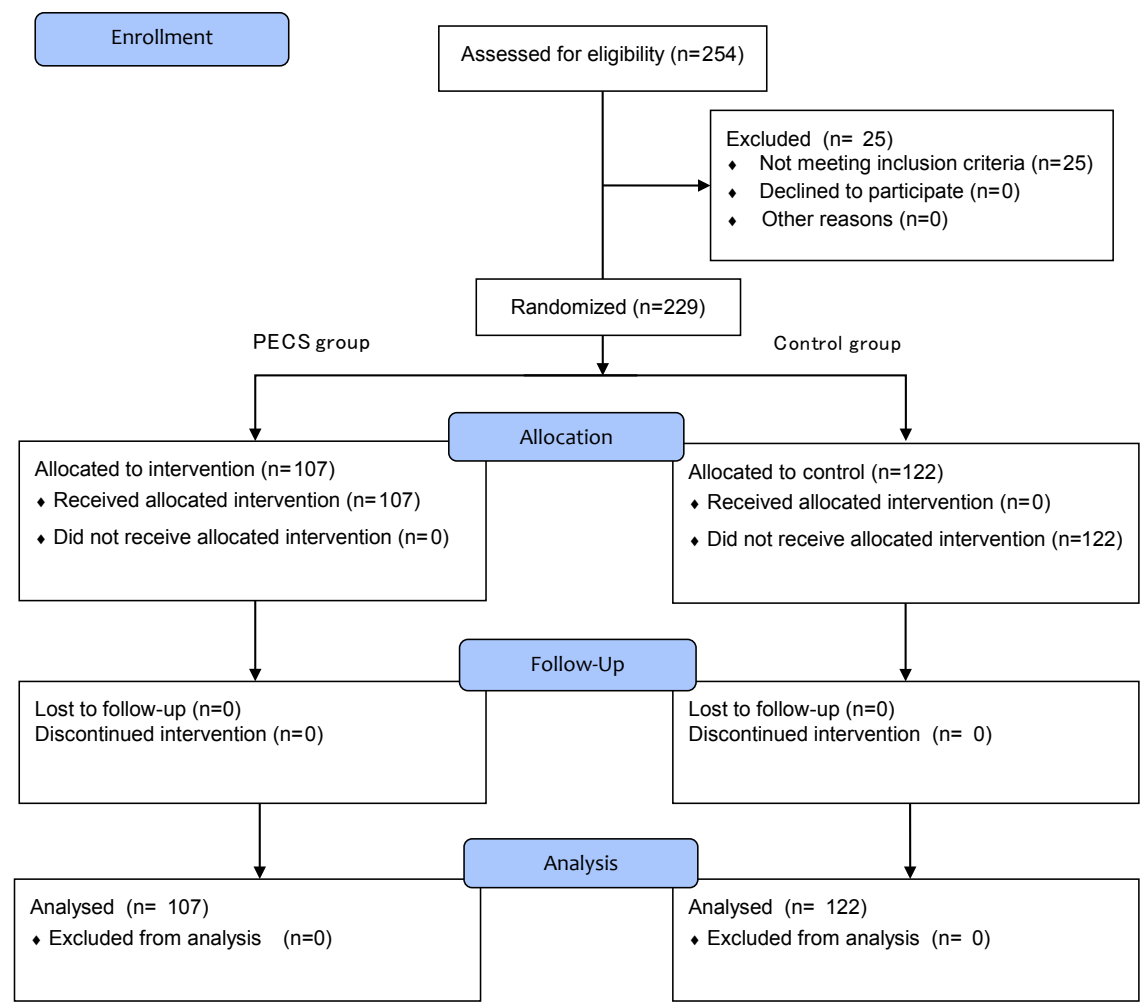

Figure 1. Flowchart of this study.

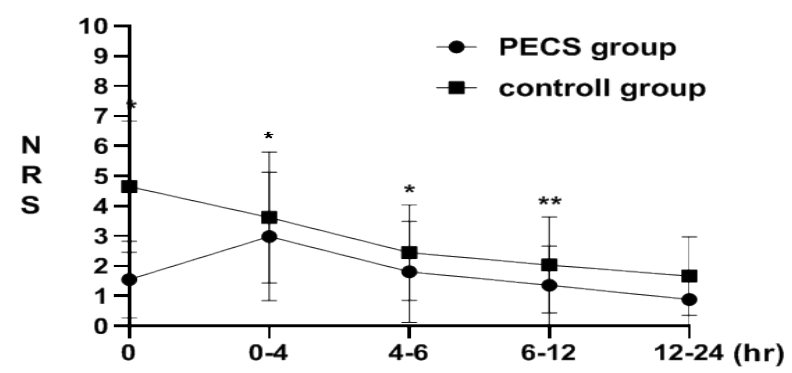

Figure 2. Postoperative NRS score at 0, $0-4,4-6,6-12$, 12 - 24 hours postoperatively. ${ }^{\star} \mathrm{P}<0.01$; ${ }^{*} \mathrm{P}<0.05$. 